\title{
Aplikasi SIG untuk Pemetaan Tingkat Ancaman Longsor di Kecamatan Sibolangit, Kabupaten Deli Serdang, Sumatera Utara
}

\section{Riki Rahmad ${ }^{1}$, Suib ${ }^{2}$ dan Ali Nurman ${ }^{3}$}

Jurusan Pendidikan Geografi, Fakultas Ilmu Sosial, Universitas Negeri Medan, Indonesia ${ }^{123}$

Email koresponden: rikirahmad@unimed.ac.id

Diterima: Januari 2018 /Disetujui: Februari 2018 / Publikasi online: Maret 2018

(๑) 2018 Fakultas Geografi UGM dan Ikatan Geograf Indonesia (IGI)

\begin{abstract}
Abstrak Tujuan penelitian ini adalah mendeskripsikan pemanfaatan SIG dalam pemetaan tingkat kerawanan terjadinya bencana longsor di Kecamatan Sibolangit, Kabupaten Deli Serdang, Sumatera Utara. Model yang digunakan mengacu pada pendugaan Puslittanak 2004, parameter-parameter yang digunakan untuk menentukan tingkat kerawanan adalah penutupan lahan (landcover), jenis tanah, kemiringan lahan, curah hujan dan formasi geologi (batuan induk). Pada proses pemetaan setiap parameter memiliki klasifikasi skor yang dikalikan dengan bobot masing-masing parameter, kemudian hasil perkalian skor dan bobot tersebut dijumlahkan berdasarkan kesesuaian lokasi geografisnya. Hasil penelitian menunjukkan bahwa daerah Kecamatan Sibolangit memiliki potensi terjadinya tanah longsor dari tingkat rendah sampai dengan tinggi. Berdasarkan model pendugaan bencana tanah longsor tersebut di daerah penelitian dominan memiliki tingkat ancaman longsor dengan kelas kerawanan sedang meliputi 14 desa. Selain itu tingkat kerawanan longsor kelas kerawanan rendah meliputi 10 desa, tingkat kerawanan tinggi 3 desa dan tingkat kerawanan sangat tinggi 1 desa.
\end{abstract}

Kata kunci : Pemetaan, Ancaman Longsor, SIG

Abstract The purpose of this research is to describe the utilization of GIS in mapping of vulnerability of landslide disaster in Sibolangit Subdistrict, Deli Serdang Regency, North Sumatera. The model used refers to the estimation of Puslittanak 2004, the parameters used to determine the level of vulnerability are the land cover, soil type, land slope, rainfall and geological formation (rocks). In the process of mapping each parameter has a classification score multiplied by the weight of each parameter, then the results of the multiplication of the score and weight are summed based on the suitability of geographical location. The results showed that the District of Sibolangit has the potential for landslides from low to high levels. Based on the prediction model of landslide disaster in the dominant research area has a landslide threat level with vulnerability class covering 14 villages. In addition, the low vulnerability of low vulnerability landslide includes 10 villages, high level of vulnerability of 3 villages and very high level of vulnerability 1 villages.

Key words: Mapping, Landslide Threats, GIS

\section{PENDAHULUAN}

Tanah longsor adalah gerakan tanah berkaitan langsung dengan berbagai sifat fisik alami seperti struktur geologi, bahan induk, tanah, pola drainase, lereng/bentuk lahan, hujan maupun sifat-sifat nonalami yang bersifat dinamis seperti penggunaan lahan dan infra-struktur (Barus 1999). Menurut Suripin (2002) tanah longsor merupakan bentuk erosi dimana pengangkutan atau gerakan masa tanah terjadi pada suatu saat dalam volume yang relatif besar. Wang et al. (2017) mengatakan bahwa kejadian tanah longsor berhubungan dengan berbagai faktor seperti presipitasi, geologi, jarak dari patahan, vegetasi, dan topografi.

Tingginya tingkat kerugian yang dialami oleh masyarakat yang diakibatkan karena terjadinya bencana alam disebabkan karena kurangnya informasi yang diperoleh masayarakat akan kemungkinankemungkinan bencana yang terjadi disekitarnya, sehingga kesadaran masyarakat akan tanggap bencana menjadi sangat minim. Oleh karena itu, informasi awal mengenai potensi dan risko bencana merupakan salah satu media informasi yang dapat digunakan sebagai pendidikan dasar tanggap bencana bagi masyarakat (Damanik, 2012).

Bencana tanah longsor merupakan salah satu bencana alam yang sering terjadi di Indonesia dan umumnya sering terjadi di wilayah pegunungan serta pada musim hujan. Menurut Sartohadi (2008), jumlah kejadian bencana tanah longsor tertinggi di Indonesia terjadi pada wilayah yang memiliki topografi yang curam dan memiliki curah hujan 2000mm/tahun. Bencana ini berkaitan erat dengan kondisi alam seperti jenis tanah, jenis batuan, curah hujan, kemiringan lahan dan penutup lahan. Selian itu faktor manusia sangat mempengaruhiterjadinyabencanatanahlongsor, seperti alih fungsi lahan hutan yang tidak mengikuti aturan dan semena-semena, penebangan hutan tanpa melakukan 
tebang pilih, perluasan pemukiman di daerah dengan topografi yang curam. Daerah Kecamatan Sibolangit merupakan wilayah daratan tinggi dengan ketinggian 400-700 m diatas permukaan laut. Daerah dataran tinggi Sibolangit memiliki topografi kasar dengan relief perbukitan bergelombang dengan kemiringan lereng bekisar antara $60^{\circ}-90^{\circ}$. Dengan kemiringan lereng yang sangat tinggi maka potensi terjadinya longsor sangat besar. Selain itu curah hujan yang tinggi di Kecamatan Sibolangit menjadi faktor yang menyebabkan terjadi longsor.

Sibolangit terdiri dari beberapa daerah yang rawan terjadi pergerakan tanah, dengan desa yang rawan terjadi longsor yaitu Desa Sibolangit, dan Desa Bandar Baru. Kedua desa ini memiliki kemiringan lereng yang berpotensi terjadinya longsoran. Desa Sibolangit memiliki kemiringan lereng $80-90^{\circ}$, sedangkan Desa Bandar baru memiliki kemiringan lereng $60-70^{\circ}$, yang masing-masing desa ini memiliki curah hujan yang tinggi tiap tahunnya. Berdasarkan Peta Prakiraan Potensi Terjadi Gerakan Tanah pada Bulan Maret 2017 di Provinsi Sumatera Utara (Badan Geologi), daerah Sibolangit merupakan daerah bencana termasuk zona potensi terjadi gerakan tanah menengah-tinggi. Artinya, daerah tersebut mempunyai potensi menengah hingga tinggi untuk terjadi gerakan tanah. Pada zona ini dapat terjadi gerakan tanah jika curah hujan diatas normal, terutama pada daerah yang berbatasan dengan lembah sungai, gawir, tebing jalan atau jika lereng mengalami gangguan. Gerakan tanah lama dapat aktif kembali. Selain faktor kondisi fisik wilayah yang berpotensi terjadinya longsoran tanah, faktor sosial masyarakat juga menjadi penyebab terjadinya tanah longsor di Sibolangit. Di mana banyaknya terjadinya penebangan hutan secara ilegal, dan terjadi pembukaan hutan untuk dijadikan ladang oleh penduduk sekitar. Alih fungsi lahan dari hutan menjadi permukiman dan sebagainya meyebabkan semakin cepatnya pergerakan tanah dan terjadinya tanah longsor, ataupun longsoran batuan. Bencana tanah longsor yang berulang kali terjadi di sibolangit akhir-akhir ini sangat meresahkan, banyak yang menjadi korban akibat bencana alam ini, baik korban jiwa dan materi.

Berbagai masalah terkait dengan bencana tanah longsor Di Kecamatan Sibolangit yang melatar belakangi penelitian yang dilakukan kelompok peneliti. Tindak lanjut dari permasalahan ini yaitu mencari solusi dan langkah tepat untuk mengatasi dan mengurangi dampak terjadinya tanah longsor. Salah satu langkah yang dapat dilakukan untuk mengurangi dampak tanah longsor adalah dengan mengenali karakteristik daerah rawan terjadinya longsor tersebut, yang mana untuk mengenali kararteritistik daerah terjadinya bencana tanah longsor maka diperlukan sebuah pemetaan daerah rawan bencana tanah longsor. Pemetaan daerah rawan bencana tanah longsor dapat dilakukan dengan pemanfaatan Sistem Informasi Geografis (SIG). Dengan menggunakan Sistem informasi Geografis dapat dimuat berbagai informasi geospasial yang berkaitan dengan berbagai faktor penyebab tanah longsor. Pemetaan daerah rawan bencana tanah longsor ini dapat dilakukan dengan menggunakan berbagai aplikasi atau software pemetaan pada SIG, seperti dengan menggunakan ArcGIS dengan berbagai type nya. Dengan pemetaan daerah rawan bencana tanah longsor di Kecamatan Sibolangit, maka dampak dari bencana dapat diminimalisir dan dapat dilakukan tindakan yang bersifat preventif terhadap daerah dengan kategori tingkat kerawanan tinggi.

Terdapat beberapa pencapaian penelitian mengenai pemetaan kerawanan longsor. Rahman (2010) menggunakan parameter intensitas curah hujan, kemiringan lereng, geologi, penggunaan lahan, permeabilitas tanah, tekstur tanah, serta kedalaman tanah dalam menentukan kerawanan longsor. Penelitian serupa juga dilakukan oleh Zakaria (2010). Stabilisasi dan rancang bangun lereng terpadu (Starlet) yang dirumuskan oleh Zakaria (2010) merupakan suatu usulan dalam penanganan lereng rawan longsor yang melibatkan keterpaduan antara sistem pemetaan longsoran dan lereng rawan longsor, analisis kestabilan lereng sebagai peringatan dini maupun untuk stabilisasi, simulasi rancang bangun lereng stabil, dan arahan manajemen lingkungan yang disertai monitoring lingkungan, dengan melibatkan peran para ilmuwan, aparat pemerintah, masyarakat, dan pengusaha dalam menghadapi bencana longsor ini. Dalam penelitian Faizana et al. (2015), pembuatan peta risiko bencana tanah longsor dilakukan dengan beberapa tahapan yaitu pemodelan peta ancaman, pemodelan kerentanan, pemodelan kapasitas, serta pemodelan risiko. Pemodelan ancaman dihasilkan dari pembobotan menggunakan overlay.

Adapun judul penelitian yang diangkat oleh kelompok peneliti adalah "Aplikasi SIG Untuk Pemetaan Tingkat Ancaman Longsor Di Kecamatan Sibolangit, Kabupaten Deli Serdang". Tujuan penelitian ini antara lain: (1) Mendeskripsikan tingkat ancaman longsor di Kecamatan Sibolangit, Kabupaten Deli Serdang, Sumatera Utara berdasarkan faktor-faktor yang mempengaruhi terjadinya tanah longsor; (2) Mendeskripsikan pemanfaatan SIG dalam pemetaan tingkat kerawanan terjadinya bencana longsor di Kecamatan Sibolangit, Kabupaten Deli Serdang, Sumatera Utara. 


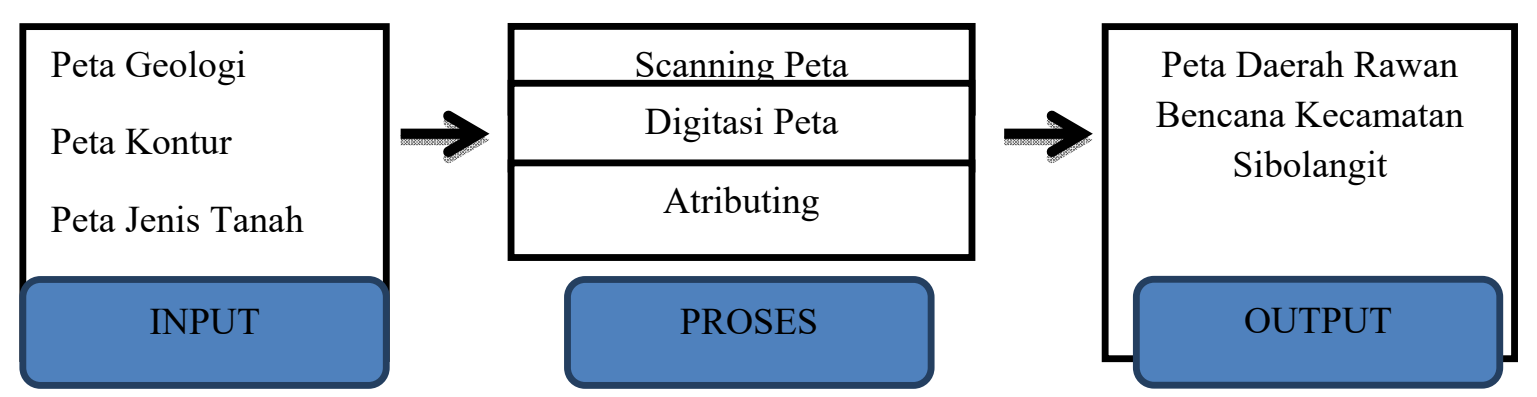

Gambar 1. Diagram Alir Penelitian

\section{METODE PENELITIAN}

Lokasi penelitian pemetaan daerah rawan bencana longsor ini dilakukan di Kecamatan Sibolangit, Kabupaten Deli Serdang, Sumatera Utara. Penelitian ini dilakukan pada November 2017. Bahan dan alat dalam penelitian Pemanfaatan SIG untuk pemetaan tingkat ancaman longsor tingkat ancaman longsor di

Kecamatan Sibolangit, Kabupaten Deli Serdang adalah Peta jenis batuan Kecamatan Sibolangit, Peta jenis tanah Kecamatan Sibolangit, Peta penggunaan lahan Kecamatan Sibolangit dan Peta curah hujan dan datadata lainnya terkait dengan tanah, penutup lahan, curah hujan dan kemiringan lereng di Kecamatan Sibolangit.

Data berupa peta curah hujan, peta jenis tanah, peta geologi dan peta kontur selanjutnya di Input dalam software SIG. Proses pemasukan data-data dilakukan melalui seperangkat komputer dengan software ArcGIS 10.1. Data keluaran ini kemudian digunakan sebagai data acuan penentuan wilayah penelitian serta acuan analsis pemetaan daerah rawan bencana longsor di Kecamatan Sibolangit (Gambar 1).

Analisis peta kerawanan tanah longsor dilakukan setelah peta-peta tematik parameter yaitu peta curah hujan, peta jenis tanah, peta geologi, peta kemiringan lereng wilayah tersebut tersedia dan siap dalam bentuk peta digital. Setiap jenis peta tersebut dilakukan klasifikasi berdasarkan skor serta diberi bobot kemudian skor dikelompokkan dan dianalisis. Pemetaan tersebut dilakukan dengan menggunakan software ArcGIS 10.1. Pada proses pemetaan setiap parameter memiliki klasifikasi skor yang dikalikan dengan bobot masingmasing parameter menurut model pendugaan Puslittanak 2004, kemudian hasil perkalian skor dan bobot tersebut dijumlahkan berdasarkan kesesuaian lokasi geografisnya. Model pendugaan Puslittanak 2004, parameter-parameter yang digunakan untuk menentukan tingkat kerawanan adalah penutupan lahan (landcover), jenis tanah, kemiringan lahan, curah hujan dan formasi geologi (batuan induk) (Tabel 1-5).

Model yang digunakan untuk menganalisis kerawanan kongsor adalah model pendugaan yang mengacu pada penelitian Puslittanak tahun 2004 dengan formula :
SKOR TOTAL $=0,3 \mathrm{FCH}+0,2 \mathrm{FBD}+0,2 \mathrm{FKL}+0,2 \mathrm{FPL}$ $+0,1$ FJT

Keterangan:

$\begin{array}{ll}\mathrm{FCH} & =\text { Faktor Curah Hujan } \\ \mathrm{FBD} & =\text { Faktor Jenis Batuan } \\ \text { FKL } & =\text { Faktor Kemiringan Lereng } \\ \text { FPL } & =\text { Faktor Penutupan Lahan } \\ \text { FJT } & =\text { Faktor Jenis Tanah } \\ 0,3 ; 0,2 ; 0,1 & =\text { Bobot nilai }\end{array}$

Tabel 1. Klasifikasi Curah Hujan (mm/tahun)

\begin{tabular}{lcc}
\hline \multicolumn{1}{c}{ Parameter } & Bobot & Skor \\
\hline Sangat basah $(>3000)$ & & 5 \\
Basah $(2501-2300)$ & & 4 \\
Sedang $(2001-2500)$ & $30 \%$ & 3 \\
Kering (1501-2000) & & 2 \\
Sangat kering $(<1500)$ & & 1
\end{tabular}

Sumber : Puslittanak Bogor (2004)

Tabel 2. Klasifikasi Jenis Batuan

\begin{tabular}{lcc}
\hline \multicolumn{1}{c}{ Parameter } & Bobot & Skor \\
\hline Batuan vulkanik & & 3 \\
Batuan sedimen & $20 \%$ & 2 \\
Batuan aluvial & & 1 \\
\hline
\end{tabular}

Sumber : Puslittanak Bogor (2004)

Tabel 3. Klasifikasi Kemiringan Lahan

\begin{tabular}{ccc}
\hline Parameter (\%) & Bobot & Skor \\
\hline$>45$ & & 5 \\
$30-45$ & & 4 \\
$15-30$ & $20 \%$ & 3 \\
$8-15$ & & 2 \\
$<8$ & & 1 \\
\hline
\end{tabular}

Sumber : Puslittanak Bogor (2004) 


\begin{tabular}{lcc}
\hline \multicolumn{2}{c}{ Tabel 4. Klasifikasi Penutup Lahan } \\
\hline \multicolumn{1}{c}{ Parameter } & Bobot & Skor \\
\hline Tegalan, sawah & & 5 \\
Semak belukar & & 4 \\
Hutan dan perkebunan & $20 \%$ & 3 \\
Kota/permukiman & & 2 \\
Tambak, waduk, perairan & & 1 \\
\hline
\end{tabular}

Sumber : Puslittanak Bogor (2004)

Tabel 5. Klasifikasi Jenis Tanah

\begin{tabular}{lcc}
\hline \multicolumn{1}{c}{ Parameter } & Bobot & Skor \\
\hline Regosol & & 5 \\
Andosol, podsolik & & 4 \\
Latosol coklat & $10 \%$ & 3 \\
Asosiasi latosol cokltak kekuningan & & 2 \\
Aluvial & & 1 \\
\hline
\end{tabular}

Sumber : Puslittanak Bogor (2004)

Klasifikasi hasil akhir dengan analisis skor dan dilakukan dengan membuat 4 kelas kerawanan longsor yaitu : rendah, sedang, tinggi dan sangat tinggi berdasarkan jumlah skor akhir, semakin besar jumlah skor maka semakin tinggi tingkat kerawanan, dengan penentuan selang skor:

\section{Skor Tertinggi - Skor Terendah Jumlah Kelas Klasifikasi}

\section{HASIL DAN PEMBAHASAN}

Secara astronomis kecamatan Sibolangit terletak pada $3^{0} 24^{\prime} \mathrm{LU}-3^{0} 37^{\prime} \mathrm{LU}$ dan $98^{\circ} 56^{\prime} \mathrm{BT}-98^{\circ}$ 60 ' BT (Gambar 2). Dengan ketinggian 300-700 m diata permukaan laut. Adapun secara geografis Kecamatan Sibolangit berada di Kabupaten Deli Serdang dan batas administratif wilayah Kecamatan Sibolangit berbatasan dengan Kabupaten Karo. Batas administrasi Kecamatan Sibolangit yaitu Sebelah Utara berbatasan dengan Kecamatan Pancur Batu, sebelah Selatan berbatasan dengan Kabupaten Karo, sebelah Timur berbatasan dengan Kecamatan Sibiru-Biru, Kecamatan Namorambe dan sebelah Barat berbatasan dengan Kecamatan Kutalimbaru.

Kecamatan Sibolangit Kabupaten Deli Serdang, berjarak sekitar $50 \mathrm{Km}$ dari kota Medan, dengan luas wilayah sekitar $165,26 \mathrm{Km}^{2}$.

\section{Faktor-Faktor Yang Mempengaruhi Longsor Kecamatan Sibolangit \\ Curah Hujan}

Berdasarkan data dari peta RTRW Sumatera Utara terkait peta curah hujan. Dimana curah hujan di lokasi penelitian termasuk tinggi yaitu antara 1501$2500 \mathrm{~mm} /$ tahun. Sebagai salah satu parameter untuk menentukan wilayah rawan longsor, faktor-faktor curah hujan seperti besarnya curah hujan, intensitas hujan dan distribusi curah hujan akan menentukan seberapa besar peluang terjadinya longsoran dan di mana longsor itu akan terjadi. Untuk lebih jelasnya curah hujan di Kecamatan Sibolangit dapat dilihat pada Gambar 3.

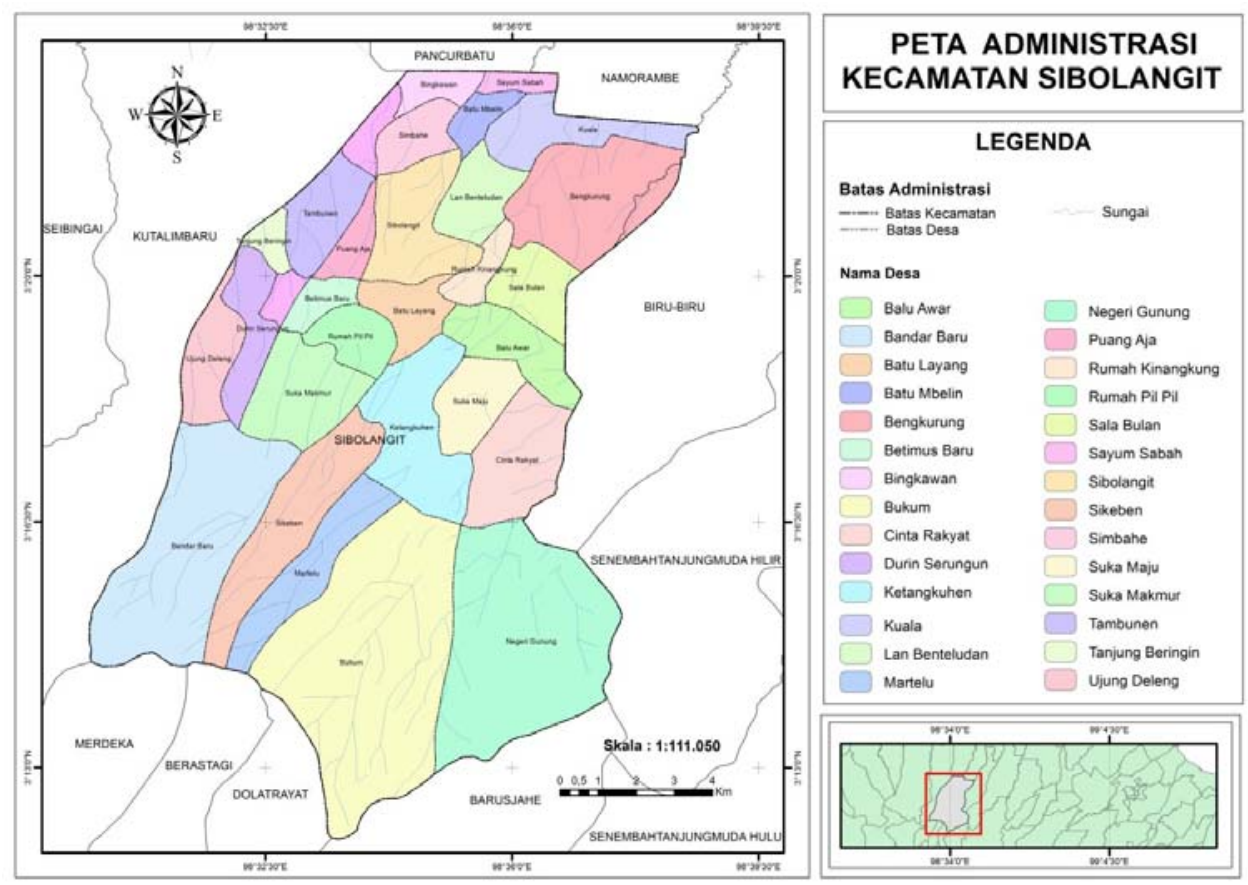

Gambar 2. Peta Kecamatan Sibolangit 


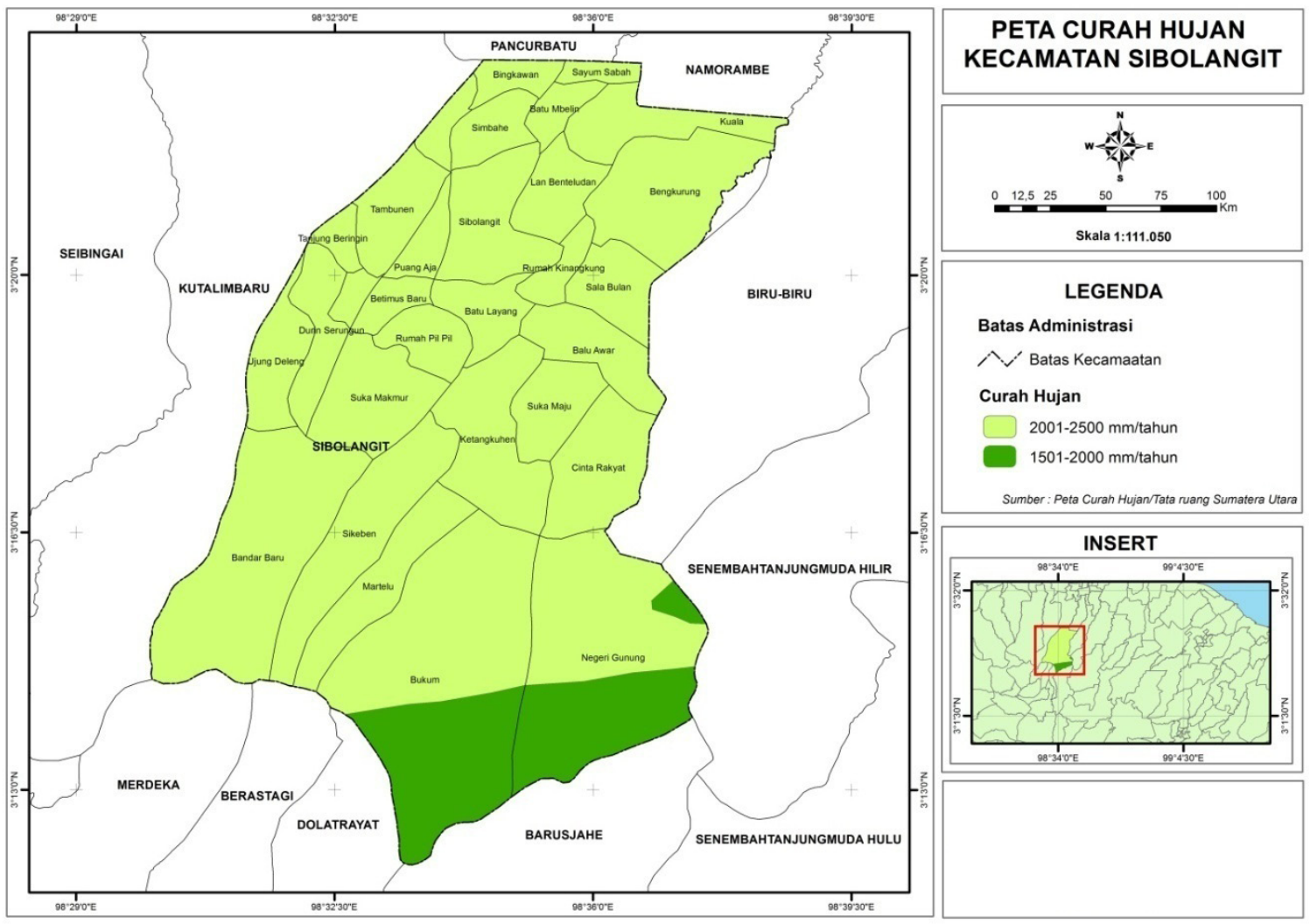

Gambar 3. Peta Curah Hujan Kecamatan Sibolangit

Tabel 7. Klasifikasi Curah Hujan Menurut Desa di Kecamatan Sibolangit

\begin{tabular}{lclc}
\hline \multicolumn{1}{c}{ Desa } & Skor & \multicolumn{1}{c}{ Desa } & Skor \\
\hline Bandar Baru & 3 & Tanjung Beringin & 3 \\
Sikeben & 3 & Tambunen & 3 \\
Martelu & 3 & Puang Aja & 3 \\
Bukum & 5 & Betimus Mbaru & 3 \\
Negeri Gunung & 5 & Rumah Kinangkung & 3 \\
Cinta Rakyat & 3 & Sala Bulan & 3 \\
Ketangkuhen & 3 & Bengkurung & 3 \\
Suka Maju & 3 & Kuala & 3 \\
Bulu Awar & 3 & Batu Mbelin & 3 \\
Batu Layang & 3 & Sibolangit & 3 \\
Rumah Pipil & 3 & Sembahe & 3 \\
Suka Makmur & 3 & Bingkawan & 3 \\
Durin Serungun & 3 & Sayum Sabah & 3 \\
Ujung Deleng & 3 & Lan Benteludan & 3 \\
Sumber: Data RTRW Deli Serdang diolah 2017
\end{tabular}

Berdasarkan klasifikasi kelas curah hujan Puslittanak, lokasi penelitian memiliki dua kelas curah hujan yaitu 1501-2000 mm/tahun dan 2001-2500 mm/ tahun.
Curah hujan dengan intensitas 2001-2500 $\mathrm{mm} /$ tahun merupakan intensitas curah hujan yang memiliki luasan terbesar yaitu meliputi 28 desa (Tabel 7). Disamping itu terdapat 2 desa memiliki sebagian daerahnya dengan tingkat curah hujan berkisar antara 1501-2000 (kering). Adapun menurut tabel terdapat desa yang memiliki skor 5 yaitu desa Negeri Gunung dan Desa Bukum, karena memiliki daerah yang terdiri atas dua parameter curah hujan yaitu 1501-2000 mm/ tahun dan 2001-2500 mm/tahun. Terdapat 26 desa yang memiliki skor 3 dengan curah hujan berkisar 2001-2500 mm/tahun.

\section{Jenis Batuan}

Secara geologi lokasi penelitian merupakan wilayah dengan struktur batuan yang sangat dipengaruhi oleh kondisi Gunung Sibayak, dan Barus. Sifat-sifat teknis batuan berbeda-beda tergantung pada asal-usulnya. Secara umum sifat-sifat teknis batuan dipengaruhi oleh : struktur dan tekstur, kandungan mineral, kekar/bentuk gabungan lapisan bidang dasar, kondisi cuaca, dan sedimentasi/rekatan. Jenis batuan di Kecamatan Sibolangit untuk lebih jelasnya dapat dilihat pada Gambar 4. 


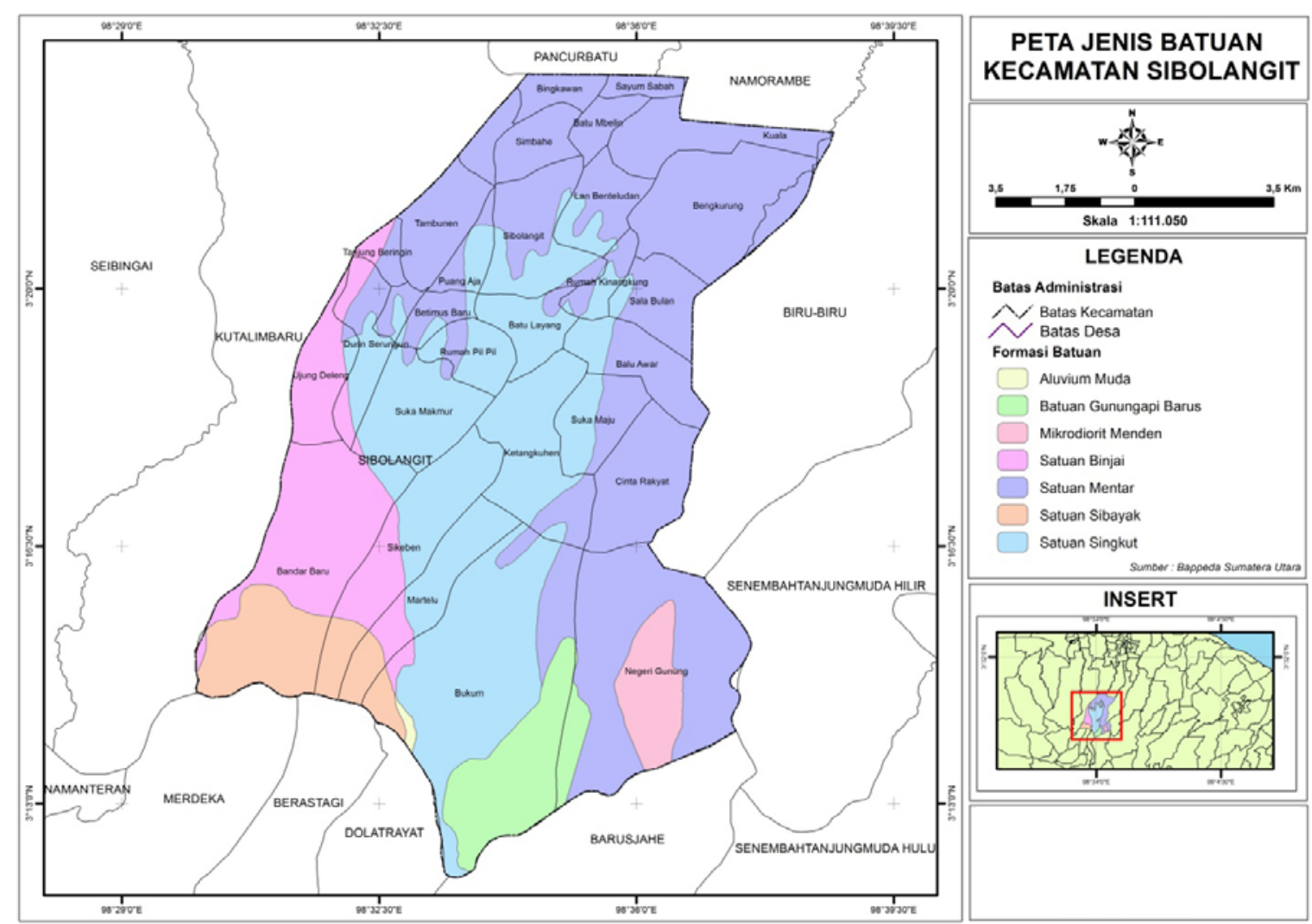

Gambar 4. Peta Jenis Batuan Kecamatan Sibolangit

Berdasarkan pengklasifikasian Puslittanak batuan pembentuk yang terdapat di lokasi penelitian terdiri dari 2 jenis batuan yaitu batuan Vulkanik, dan batuan Aluvial. Batuan Vulkanik terdiri atas formasi batuan gunung api barus (Qvbr), mikrodiorit menden (Qtim), satuan binjai (Qvbj), satuan mentar (QTvm), satuan sibayak (Qvba) dan satuan singkut (Qvbs). Batuan Aluvial yang terdapat di lokasi penelitian adalah satuan aluvium muda (Qh) (Gambar 8).

Tabel 8. Formasi Batuan Kecamatan Sibolangit

\begin{tabular}{|c|c|c|c|c|c|}
\hline Desa & Formasi Batuan & Skor & Desa & Formasi Batuan & Skor \\
\hline Bandar Baru & Qvba,Qvbj & 6 & Tanjung Beringin & Qvbj, QTvm & 6 \\
\hline Sikeben & Qvba,Qvbj, Qvbs & 9 & Tambunen & QTvm & 3 \\
\hline Martelu & Qvba,Qvbj, Qvbs & 9 & Puang Aja & Qvbs, QTvm & 6 \\
\hline \multirow[t]{2}{*}{ Bukum } & Qvba, Qvbj, Qvbs, & 16 & Betimus Mbaru & Qvbs, QTvm & 6 \\
\hline & Qvbr, QTvm, Qh & & Rumah Kinangkung & Qvbs, QTvm & 6 \\
\hline Negeri Gunung & Qtim, QTvm, Qvbr & 9 & Sala Bulan & Qvbs, QTvm & 6 \\
\hline Cinta Rakyat & QTvm & 3 & Bengkurung & QTvm & 3 \\
\hline Ketangkuhen & Qvbs, QTvm & 6 & Kuala & QTvm & 3 \\
\hline Suka Maju & Qvbs, QTvm & 6 & Batu Mbelin & QTvm & 3 \\
\hline Bulu Awar & Qvbs, QTvm & 6 & Sibolangit & Qvbs, QTvm & 6 \\
\hline Batu Layang & Qvbs & 3 & Sembahe & QTvm & 3 \\
\hline Rumah Pipil & Qvbs, QTvm & 6 & Bingkawan & QTvm & 3 \\
\hline Suka Makmur & Qvbs, QTvm & 6 & Sayum Sabah & QTvm & 3 \\
\hline Durin Serungun & Qvbj, Qvbs, QTvm & 9 & Lan Benteludan & Qvbs, QTvm & 6 \\
\hline Ujung Deleng & Qvbj, Qvbs, QTvm & 9 & & & \\
\hline
\end{tabular}

Sumber : Data RTRW Deli Serdang diolah 2017 


\section{Jenis Tanah}

Jenis Tanah di lokasi penelitian berdasarkan Peta Tanah lokasi penelitian terdiri dari tanah Podsolik, Andosol, Latosol, Regosol, Aluvial (Tabel 9). Mengacu pada klasifikasi Puslittanak berdasarkan kepekaan terhadap erosi, maka jenis tanah di lokasi penelitian terbagi menjadi kelas Sangat Peka Erosi/Permeabilitas sangat Lambat (Regosol), Peka Erosi/Permeabilitas Lambat (Podsolik, dan Andosol), Agak Peka Erosi/ Permeabilitas Cepat (Latosol), dan Tidak Peka Erosi/ Permeabilitas Sangat Cepat (Aluvial dan Glei). Distribusi spasial jenis tanah di lokasi penelitian dapat dilihat pada (Gambar 5).

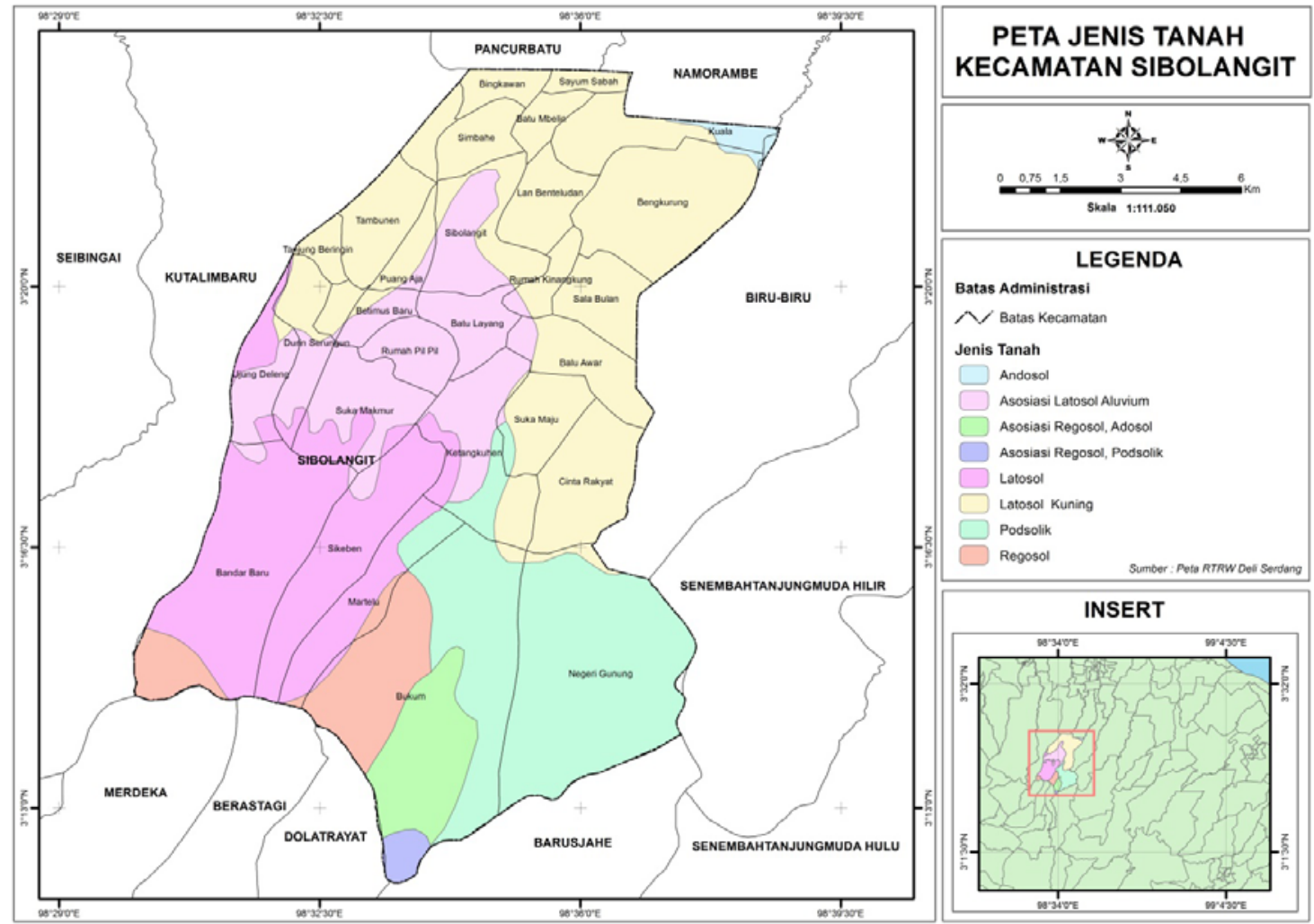

Gambar 5. Peta Jenis Tanah Kecamatan Sibolangit

Tabel 9. Tabel Jenis Tanah Kecamatan Sibolangit

\begin{tabular}{lcclcc}
\hline \multicolumn{1}{c}{ Desa } & Jenis Tanah & Skor & \multicolumn{1}{c}{ Desa } & Jenis Tanah & Skor \\
\hline Bandar Baru & R, LA, L & 12 & Tanjung Beringin & LK & 2 \\
Sikeben & L, LA & 7 & Tambunen & LK & 2 \\
Martelu & R, P, L & 12 & Puang Aja & LA, LK, & 6 \\
Bukum & RA, RP, R & 13 & Betimus Mbaru & LA, LK & 6 \\
Negeri Gunung & P & 4 & Rumah Kinangkung & LA, LK & 6 \\
Cinta Rakyat & LK & 2 & Sala Bulan & LK & 2 \\
Ketangkuhen & P, L, LA & 11 & Bengkurung & LK & 2 \\
Suka Maju & LK, P, LA & 10 & Kuala & LK & 6 \\
Bulu Awar & LK & 2 & Batu Mbelin & LA,LK & 2 \\
Batu Layang & LA & 4 & Sibolangit & LK & 2 \\
Rumah Pipil & LA & 4 & Sembahe & LK & 2 \\
Suka Makmur & L, LA & 7 & Bingkawan & 2 \\
Durin Serungun & LA, L, LK & 9 & Sayum Sabah & LK & 2 \\
Ujung Deleng & LA, L, LK & 9 & Lan Benteludan & & \\
\hline Sumber: Data RTRW Den & & & & & \\
\hline
\end{tabular}

Sumber : Data RTRW Deli Serdang diolah 2017

$\mathrm{A}=$ Andisol, $\mathrm{LA}=$ Latosol Aluvium, RA = Regosol Andisol, RP = Regosol Podsolik, L= Latosol, LK = Latosol Kuning, $\mathrm{P}=$ Podsolik, $\mathrm{R}=$ Regosol. 


\section{Kemiringan Lereng}

Kemiringan Lahan di lokasi penelitian bervariasi mulai dari datar sampai curam. Berdasarkan hasil klasifikasi menurut Puslittanak yang terdiri atas $>45 \%, 30-45 \%, 15-30 \%, 8-15 \%,<8 \%$, maka daerah penelitian memiliki kemiringan lereng antara lain $>40 \%, 15-40 \%$ dan 2-15\% (Gambar 6). Daerah lokasi penelitian merupakan daerah yang memiliki topografi kasar, dengan bentuk lahan perbukitan yang memiliki ketinggian 300-700 m dpl.
Berdasarkan data pada Tabel 10 dapat diketahui bahwa sebanyak sembilan belas desa yang memiliki kemiringan lereng 15-40\%, enam desa memiliki kemiringan lereng antara 2-40\%,dua desa memiliki kemiringan 2-15\%, dan satu desa memiliki kemiringan lereng $40 \%$ dan $>40 \%$. Secara keseluruhan daerah penelitian memiliki kemiringan $15-40 \%$ yang merupakan daerah perbukitan.

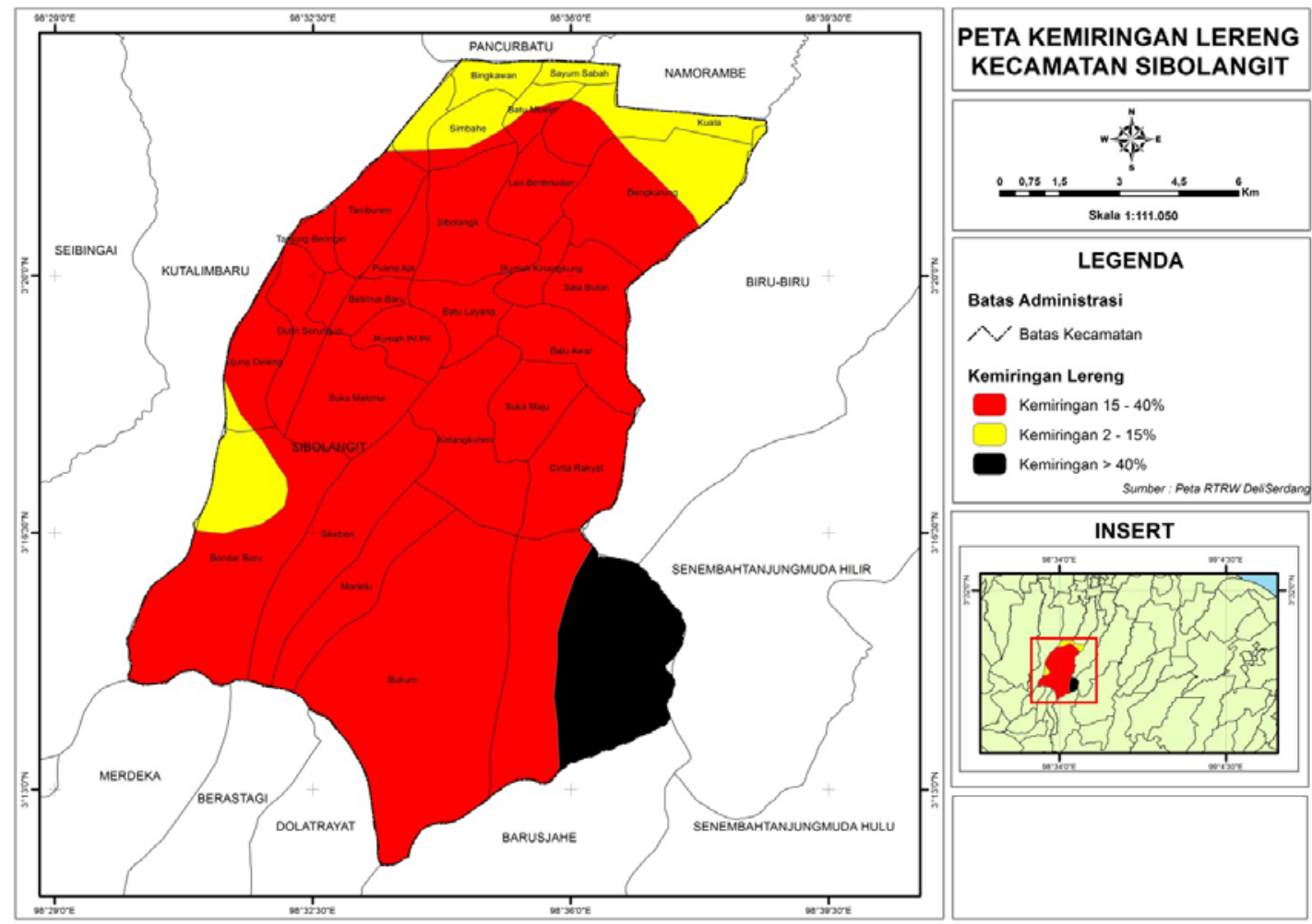

Gambar 6. Peta Kemiringan Lereng Kecamatan Sibolangit

Tabel 10. Tabel Kemiringan Lereng Kecamatan Sibolangit

\begin{tabular}{lcclcc}
\hline \multicolumn{1}{c}{ Desa } & $\begin{array}{c}\text { Kemiringan } \\
\text { Lereng }(\%)\end{array}$ & Skor & \multicolumn{1}{c}{ Desa } & $\begin{array}{c}\text { Kemiringan } \\
\text { Lereng }(\%)\end{array}$ & Skor \\
\hline Bandar Baru & $2-40$ & 6 & Tanjung Beringin & $15-40$ & 4 \\
Sikeben & $15-40$ & 4 & Tambunen & $15-40$ & 4 \\
Martelu & $15-40$ & 4 & Puang Aja & $15-40$ & 4 \\
Bukum & $15-40$ & 4 & Betimus Mbaru & $15-40$ & 4 \\
Negeri Gunung & $40->40 \%$ & 9 & Rumah Kinangkung & $15-40$ & 4 \\
Cinta Rakyat & $15-40$ & 4 & Sala Bulan & $15-40$ & 4 \\
Ketangkuhen & $15-40$ & 4 & Bengkurung & $2-40$ & 6 \\
Suka Maju & $15-40$ & 4 & Kuala & $2-40$ & 6 \\
Bulu Awar & $15-40$ & 4 & Batu Mbelin & $2-40$ & 6 \\
Batu Layang & $15-40$ & 4 & Sibolangit & $15-40$ & 4 \\
Rumah Pipil & $15-40$ & 4 & Sembahe & $2-40$ & 6 \\
Suka Makmur & $15-40$ & 4 & Bingkawan & $2-15$ & 2 \\
Durin Serungun & $15-40$ & 4 & Sayum Sabah & $2-15$ & 2 \\
Ujung Deleng & $2-40$ & 6 & Lan Benteludan & $15-40$ & 4 \\
\hline Sumber: Data RTRW Deli & & & & 6 \\
\hline
\end{tabular}

Sumber : Data RTRW Deli Serdang diolah 2017 


\section{Penutupan Lahan}

Penutupan lahan di suatu wilayah berkaitan erat dengan kondisi ekonomi dan tipe masyarakat yang tinggal di wilayah tersebut. Berdasarkan hasil digitasi peta penggunaan lahan deli serdang diperoleh lima tipe penutupan lahan (Gambar 7). Dimana penutupan lahan pada peta ini memiliki kontribusi yang berbeda- beda tergantung pada sifat dan kondisi penutupan lahan tersebut seperti bentuknya berupa permukiman, perkebunan, tegalan, hutan lebat, dan persawahan. Penutupan serta lokasi penutupan lahan itu berada adalah hal-hal yang berpengaruh dalam penentuan kerawanan wilayah (Tabel 11).

Tabel 11. Tabel Penggunaan Lahan Kecamatan Sibolangit

\begin{tabular}{|c|c|c|}
\hline Desa & Penggunaan Lahan & Skor \\
\hline $\begin{array}{l}\text { Bandar Baru } \\
\text { Sikeben } \\
\text { Martelu } \\
\text { Bukum } \\
\text { Negeri Gunung } \\
\text { Cinta Rakyat } \\
\text { Ketangkuhen } \\
\text { Suka Maju } \\
\text { Bulu Awar } \\
\text { Batu Layang } \\
\text { Rumah Pipil } \\
\text { Suka Makmur } \\
\text { Durin Serungun } \\
\text { Ujung Deleng } \\
\text { Tanjung Beringin } \\
\text { Tambunen } \\
\text { Puang Aja } \\
\text { Betimus Mbaru } \\
\text { Rumah Kinangkung } \\
\text { Sala Bulan } \\
\text { Bengkurung } \\
\text { Kuala } \\
\text { Batu Mbelin } \\
\text { Sibolangit } \\
\text { Sembahe } \\
\text { Bingkawan } \\
\text { Sayum Sabah } \\
\text { Lan Benteludan }\end{array}$ & $\begin{array}{c}\text { Hutan, Perkebunan, } \\
\text { Permukiman, Hutan, Perkebunan } \\
\text { Permukiman, Perkebunan } \\
\text { Permukiman, Perkebunan, Hutan, Persawahan } \\
\text { Perkebunan, Persawahan, Hutan } \\
\text { Perkebunan, Permukiman, Persawahan } \\
\text { Perkebunan, Permukiman, Persawahan } \\
\text { Perkebunan, Permukiman, Persawahan } \\
\text { Perkebunan, Permukiman } \\
\text { Perkebunan, Permukiman, Persawahan } \\
\text { Perkebunan, Persawahan } \\
\text { Perkebunan } \\
\text { Perkebunan, Permukiman, Tegalan } \\
\text { Hutan, Perkebunan, Permukiman } \\
\text { Tegalan, Perkebunan } \\
\text { Tegalan, Perkebunan, Permukiman } \\
\text { Perkebunan } \\
\text { Perkebunan, Tegalan } \\
\text { Perkebunan, Tegalan } \\
\text { Perkebunan, Tegalan } \\
\text { Perkebunan, Permukiman } \\
\text { Perkebunan, Permukiman } \\
\text { Perkebunan, Permukiman, Tegalan } \\
\text { Perkebunan, Permukiman, Tegalan } \\
\text { Peralan, Persawahan, Perkebunan } \\
\text { Permukiman, Perkebunan } \\
\text { Perkunan, Permukiman, Tegalan }\end{array}$ & $\begin{array}{c}3 \\
5 \\
5 \\
10 \\
5 \\
8 \\
10 \\
10 \\
10 \\
5 \\
10 \\
8 \\
3 \\
10 \\
5 \\
8 \\
10 \\
3 \\
8 \\
8 \\
8 \\
5 \\
5 \\
10 \\
10 \\
8 \\
5 \\
10\end{array}$ \\
\hline
\end{tabular}

Sumber : Data RTRW Deli Serdang diolah 2017 


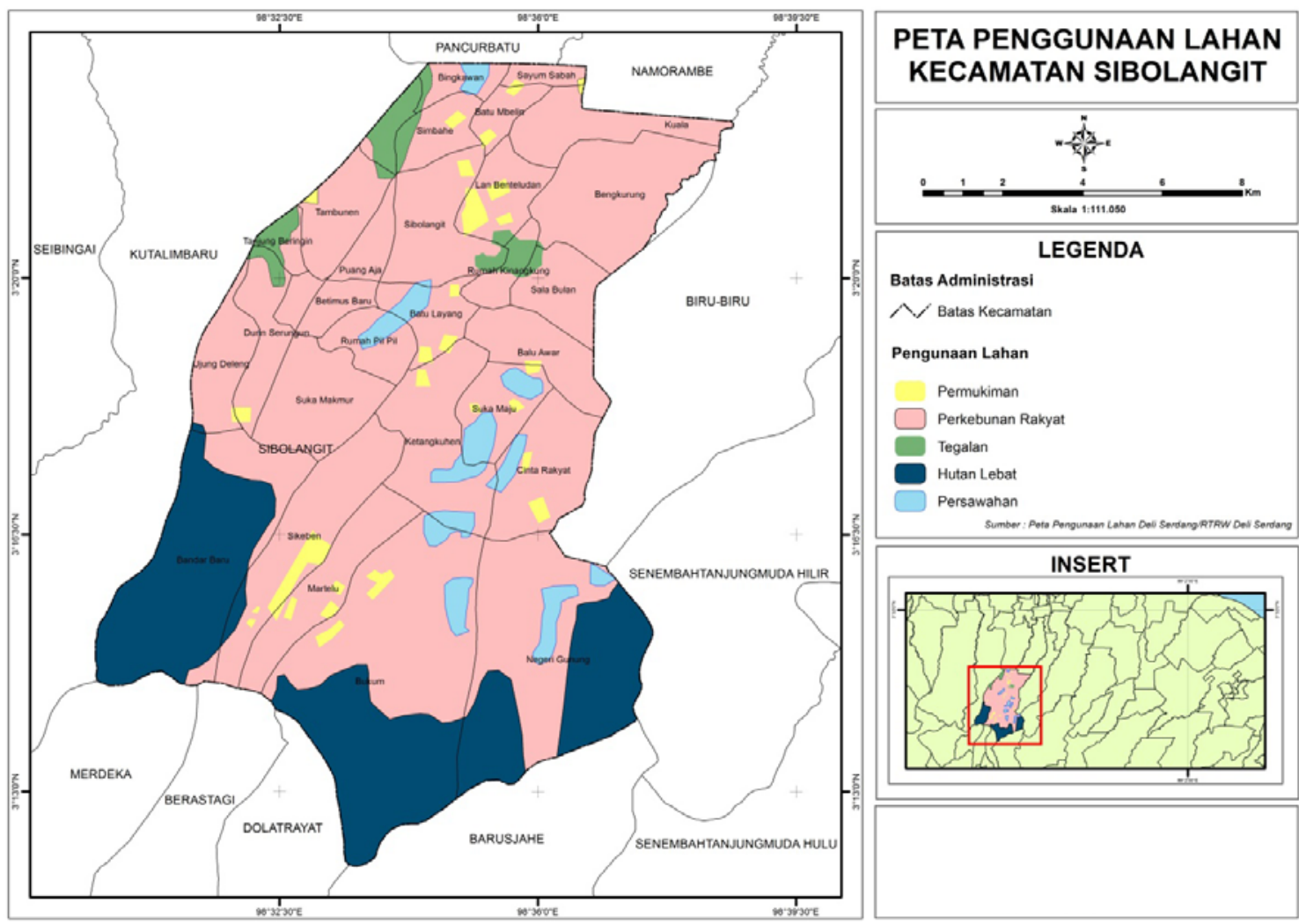

Gambar 7. Peta Penggunaan Lahan Kecamatan Sibolangit

Aplikasi SIG Dalam Pemetaan Tingkat Kerawanan Terjadinya Bencana Longsor Di Kecamatan Sibolangit, Deli Serdang

Pendugaan kawasan bencana Rawan Tanah Longsor dilakukan dengan menggunakan model pendugaan yang bersumber pada penelitian Puslittanak tahun 2004. Berdasarkan model tersebut parameter yang digunakan untuk menduga kawasan rawan longsor meliputi parameter Jenis Tanah, Penutupan Lahan, Jenis Batuan, Curah Hujan, serta Kemiringan Lahan. Semua parameter tersebut diklasifikasikan berdasarkan skor kemudian diberi bobot sesuai kontribusinya masing-masing dan kemudian data tersebut diolah. Berdasarkan hasil analisis 5 parameter kerawanan longsor dengan menggunakan model Pendugaan Kerawanan Longsor Puslittanak tahun 2004, diperoleh 4 kriteria kerawanan longsor yaitu Rendah, Sedang, Tinggi dan Sangat Tinggi. Pada model Pendugaan Kerawanan Tanah Longsor yang bersumber dari Puslittanak tahun 2004 faktor curah hujan mendapat bobot $30 \%$, faktor jenis batuan, kemiringan lahan dan tipe penutupan lahan dengan bobot $20 \%$, sedangkan faktor jenis tanah memiliki bobot $10 \%$.

Berdasarkan penjelasan tersebut, model yang digunakan untuk menganalisa kerawanan tanah longsor di lokasi penelitian adalah sebagai berikut :
SKOR TOTAL $=0,3 \mathrm{FCH}+0,2 \mathrm{FBD}+0,2 \mathrm{FKL}+0,2 \mathrm{FPL}+0,1 \mathrm{FJT}$

Keterangan:

$\mathrm{FCH}=$ Faktor Curah Hujan

FBD = Faktor Jenis Batuan

FKL = Faktor Kemiringan Lereng

FPL = Faktor Penutupan Lahan

FJT = Faktor Jenis Tanah

0,$3 ; 0,2 ; 0,1=$ Bobot nilai

Berdasarkanhasilanalisisskortotalhasil parameter yang ada di lokasi penelitian diperoleh klasifikasi kelas kerawanan dengan interval skor masing-masing kelas seperti tercantum pada Tabel 12 .

Tabel 12. Interval Skor Kelas Tingkat Kerawanan Bencana Longsor Kecamatan Sibolangit

\begin{tabular}{cc}
\hline Interval Skor (\%) & Kelas Kerawanan \\
\hline $3,1-4,5$ & Rendah \\
$4,6-6$ & Sedang \\
$6,1-7,5$ & Tinggi \\
$7,5-8,9$ & Sangat Tinggi
\end{tabular}


Berdasarkan Tabel 13-17 dan peta kerawanan bencana longsor (Gambar 8) di Kecamatan Sibolangit dapat diketahui bahwa tingkat kerawanan longsor rendah melingkup 10 desa, tingkat kerawanan longsor sedang meliputi 14 desa, tingkat kerawanan longsor tinggi meliputi 3 desa dan tingkat kerawanan sangat tinggi meliputi 1 desa.

Tabel 13. Tingkat Kerawanan Longsor Kecamatan Sibolangit

\begin{tabular}{|c|c|c|c|c|c|c|}
\hline Desa & $\begin{array}{l}\text { Skor } \\
(\%)\end{array}$ & Tingkat Kerawanan & No & Desa & $\begin{array}{l}\text { Skor } \\
(\%)\end{array}$ & $\begin{array}{c}\text { Tingkat } \\
\text { Kerawanan }\end{array}$ \\
\hline Bandar Baru & 5,1 & Sedang & 15. & Tanjung Beringin & 4,1 & Rendah \\
\hline Sikeben & 5,2 & Sedang & 16. & Tambunen & 4,1 & Rendah \\
\hline Martelu & 5,7 & Sedang & 17. & Puang Aja & 5,5 & Sedang \\
\hline Bukum & 8,8 & Sangat Tinggi & 18. & Betimus Mbaru & 4,1 & Rendah \\
\hline Negeri Gunung & 6,5 & Tinggi & 19. & Rumah Kinangkung & 5,1 & Sedang \\
\hline Cinta Rakyat & 4,1 & Sedang & 20. & Sala Bulan & 4,7 & Sedang \\
\hline Ketangkuhen & 6 & Tinggi & 21. & Bengkurung & 4,5 & Rendah \\
\hline Suka Maju & 5,9 & Sedang & 22. & Kuala & 4,3 & Rendah \\
\hline Bulu Awar & 5,1 & Sedang & 23. & Batu Mbelin & 3,9 & Rendah \\
\hline Batu Layang & 3,7 & Rendah & 24. & Sibolangit & 5,5 & Sedang \\
\hline Rumah Pipil & 5,3 & Sedang & 25. & Sembahe & 4,9 & Rendah \\
\hline Suka Makmur & 5,2 & Sedang & 26 & Bingkawan & 3,7 & Rendah \\
\hline Durin Serungun & 5 & Sedang & 27. & Sayum Sabah & 3,1 & Rendah \\
\hline Ujung Deleng & 6,8 & Tinggi & 28. & Lan Benteludan & 5,1 & Sedang \\
\hline
\end{tabular}

\section{Sumber : Data RTRW Deli Serdang diolah 2017}

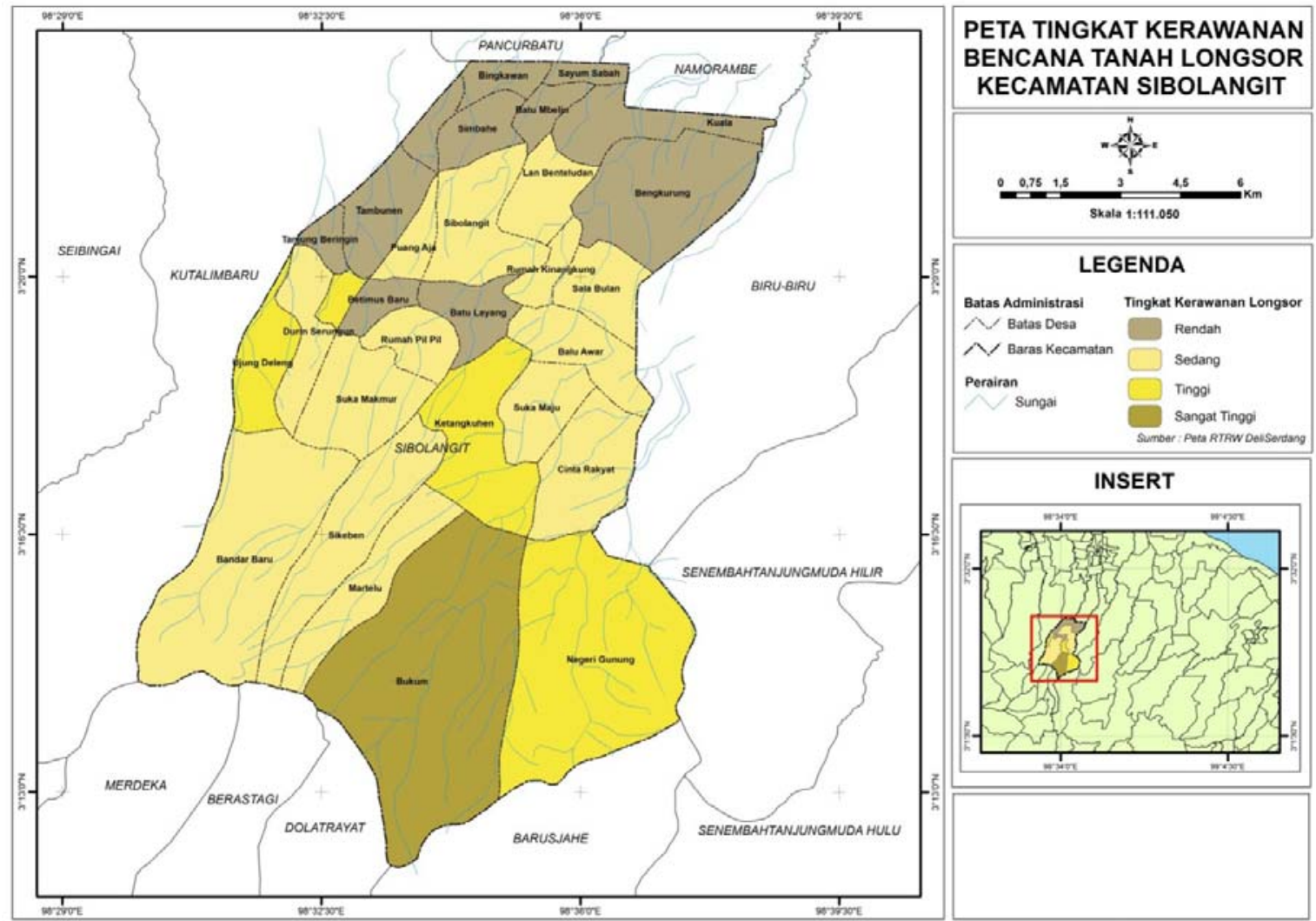

Gambar 8. Peta Kerawanan Bencana Tanah Longsor Kec. Sibolangit 


\begin{tabular}{|c|c|c|}
\hline \multicolumn{3}{|c|}{ Tabel 14. Desa Tingkat Kerawanan Rendah } \\
\hline Desa & Skor & Tingkat Kerawanan \\
\hline Batu Layang & 3,7 & Rendah \\
\hline Tanjung Beringin & 4,1 & Rendah \\
\hline Tambunen & 4,1 & Rendah \\
\hline Betimus Mbaru & 4,1 & Rendah \\
\hline Bengkurung & 4,5 & Rendah \\
\hline Kuala & 4,3 & Rendah \\
\hline Batu Mbelin & 3,9 & Rendah \\
\hline Sembahe & 4,9 & Rendah \\
\hline Bingkawan & 3,7 & Rendah \\
\hline Sayum Sabah & 3,1 & Rendah \\
\hline
\end{tabular}

Sumber : Data RTRW Deli Serdang diolah 2017

Tabel 15. Desa Tingkat Kerawanan Sedang

\begin{tabular}{|c|c|c|}
\hline Desa & Skor & Tingkat Kerawanan \\
\hline Bandar Baru & 5,1 & Sedang \\
\hline Sikeben & 5,2 & Sedang \\
\hline Martelu & 5,7 & Sedang \\
\hline Cinta Rakyat & 4,1 & Sedang \\
\hline Suka Maju & 5,9 & Sedang \\
\hline Bulu Awar & 5,1 & Sedang \\
\hline Rumah Pipil & 5,3 & Sedang \\
\hline Suka Makmur & 5,2 & Sedang \\
\hline Durin Serungun & 5 & Sedang \\
\hline Puang Aja & 5,5 & Sedang \\
\hline Rumah Kinangkung & 5,1 & Sedang \\
\hline Sala Bulan & 4,7 & Sedang \\
\hline Sibolangit & 5,5 & Sedang \\
\hline Lan Benteludan & 5,1 & Sedang \\
\hline
\end{tabular}

Sumber : Data RTRW Deli Serdang diolah 2017

Tabel 16. Desa Tingkat Kerawanan Tinggi

\begin{tabular}{lccc}
\hline & Desa & Skor & Tingkat Kerawanan \\
\hline Ketangkuhen & 6 & 6 & Tinggi \\
Ujung Deleng & & 6,8 & Tinggi \\
Negeri Gunung & 6,5 & Tinggi \\
\hline
\end{tabular}

Sumber : Data RTRW Deli Serdang diolah 2017

Tabel 17. Desa Tingkat Kerawanan Sangat Tinggi

\begin{tabular}{|c|c|c|}
\hline Desa & Skor & Tingkat Kerawanan \\
\hline Bukum & 8,8 & Sangat Tinggi \\
\hline
\end{tabular}

Sumber : Data RTRW Deli Serdang diolah 2017

Pemanfaatan SIG dalam pemetaan tingkat kerawanan bencana longsor di Kecamatan Sibolangit terkait dalam hal membuat peta dan mengolah data keruangan, meliputi data curah hujan, jenis batuan, jenis tanah, kemiringan lereng, dan jenis tutupan lahan. Dimana pada lokasi penelitian faktor yang paling dominan terhadap terjadinya longsor, yaitu curah hujan yang tinggi, batuan penyusun dan jenis tanah yang labil. Dengan pemanfaatan SIG dalam pemetaan ancaman bahaya longsor juga dapat digunakan dalam menentukan luas wilayah yang memiliki kerawanan rendah, sedang, tinggi dan sangat tinggi Tabel 18 menyajikan luas wilayah dengan tingkat kerawanan longsor di Kecamatan Sibolangit. 
Riki Rahmad, dkk/Majalah Geografi Indonesia, Vol. 32, No. 1, Maret 2018: 1 - 13

\begin{tabular}{lcc}
\hline \multicolumn{3}{c}{ Tabel 18. Luas Wilayah Menurut Potensi Tingkat } \\
Kerawanan Longsor
\end{tabular}

Sumber : Data RTRW Deli Serdang diolah 2017

\section{KESIMPUAN DAN SARAN}

Berdasarkan hasil penelitian, maka dapat disimpulkan bahwa faktor yang mempengaruhi terjadinya tanah longsor di Kecamatan Sibolangit meliputi curah hujan, jenis batuan, jenis tanah, kemiringan lereng, dan penggunaan lahan. (1)Lokasi penelitian memiliki tingkat curah hujan yang tinggi yaitu antara 1501-2500 $\mathrm{mm} /$ tahun. (2)Jenis batuan dilokasi penelitian merupakan wilayah dengan struktur batuan yang sangat dipengaruhi oleh kondisi gunung sibayak, dan barus. (3) Jenis tanah di kecamatan sibolangit terdiri atas jenis tanah Podsolik, Andosol, Latosol, Regosol, Aluvial. (4) Kemiringan lereng di Kecamatan Sibolangit yang merupakan daerah perbukitan memiliki kemiringan 2-15\%, 15-40\%, dan $>40 \%$. (5) jenis penggunaan lahan di Kecamatan Sibolangit meliputi permukiman, perkebunan rakyat, tegalan, sawah, dan hutan.

Pemanfaatan SIG dalam pemetaan ancaman bahaya longsor di Kecamatan Sibolangit dilakukan dengan mengolah data spatial dengan menggunakan model pendugaan berdasarkan puslittanak tahun 2004. Diketahui bahwa daerah Kecamatan Sibolangit memiliki potensi terjadinya tanah longsor dari tingkat rendah sampai dengan tinggi. Berdasarkan model pendugaan bencana tanah longsor tersebut di daerah penelitian dominan memiliki tingkat ancaman longsor dengan kelas kerawanan sedang meliputi 14 desa. Selain itu tingkat kerawanan longsor kelas kerawanan rendah meliputi 10 desa, tingkat kerawanan tinggi 3 desa dan tingkat kerawanan sangat tinggi 1 desa.

\section{DAFTAR PUSTAKA}

Barus, B. (1999). Landslide Hazard Mapping based on GIS Univariate Statistical Classification: Case Study of Ciawi-Puncak-Pacet Regions, West Java. Jurnal Ilmu Tanah dan Lingkungan, 2(1).

BPS Deli Serdang. 2015. https://deliserdangkab.bps. go.id/ diakses 4 November 2017

Damanik, M. R. S., \& Restu, R. (2012). Pemetaan Tingkat Risiko Banjir dan Longsor Sumatera Utara Berbasis Sistem Informasi Geografis. JURNAL GEOGRAFI, 4(1), 29-42.

Direktorat Geologi Tata Lingkungan. (1981). Gerakan Tanah di Indonesia.Jakarta: Direktorat Jenderal Pertambangan Umum. Departemen Pertambangan Dan Energi.

Direktorat Vulkanologi dan Mitigasi Bencana Geologi (DVMBG). (2005). Managemen Bencana Tanah Longsor. http://pikiranrakyat. com/cetak/2005/0305/22/0802.htm . Diakses 4 November 2017.

Faizana, F., Nugraha, A. L., \& Yuwono, B. D. (2015). Pemetaan Risiko Bencana Tanah Longsor Kota Semarang. Jurnal Geodesi Undip, 4(1), 223-234.

Nandi. (2007). Longsor. Bandung: Jurusan Pendidikan Geografi Universitas Pendidikan Indonesia (UPI). http://file.upi.edu/Direktori/diakses 4 november 2017

Paripurno, E.T. (2004). Partisipasi Masyarakat Dalam Penanggulangan Bencana Longsor, Dalam Permasalahan, Kebijakan dan Penanggulangan Bencana Tanah Longsor di Indonesia. Jakarta: P3TPSLK BPPT dan HSF.

Purwonegoro, H. (2005). Evaluasi Kawasan Lindung dengan Menggunakan Citra Satelit Landsat ETM dan Sistem Informasi Geografis (Studi Kasus di Wilayah Kabupaten Bondowoso, Jawa Timur). [Skripsi]. Departemen Konservasi Sumberdaya Hutan. IPB. Bogor

(Puslittanak) Pusat Penelitian dan Pengembangan Tanah dan Agroklimat. (2004). Laporan Akhir Pengkajian Potensi Bencana Kekeringan, Banjir dan Longsor di Kawasan Satuan Wilayah Sungai Citarum-Ciliwung, Jawa Barat Bagian Barat Berbasis Sistem Informasi Geografi. Bogor.

Rahman, A. (2010). Penggunaan Sistim Informasi Geografis untuk Pemetaan Kerawanan Longsor di Kabupaten Purworejo. Bumi Lestari, 10(2).

Sartohadi, J. (2008). The Landslide Distribution in Loano Sub-District, Purworejo District, Central Java Province, Indonesia. Forum Geografi. 22 (2), 129-144.

Suripin. (2002). Pelestarian Sumberdaya Tanah dan Air. Yogyakarta: Penerbit Andi.

Wang, F., Xu, P., Wang, C., Wang, N., \& Jiang, N. (2017). Application of a GIS-Based Slope Unit Method for Landslide Susceptibility Mapping along the Longzi River, Southeastern Tibetan Plateau, China. ISPRS International Journal of Geo-Information, 6(6), 172.

Zakaria, Z. (2010). Model Starlet, suatu Usulan untuk Mitigasi Bencana Longsor dengan Pendekatan Genetika Wilayah (Studi Kasus: Longsoran Citatah, Padalarang, Jawa). Indonesian Journal on Geoscience, 5(2), 93-112. 